\title{
Challenges and Opportunities of TVET in Developing Countries: A Case of Sudan
}

\author{
Abdelmoiz Ramadan*1,2, Chen Xiaohui ${ }^{1}$ \\ ${ }^{1}$ School of Information Science and Technology Northeast Normal University, Changchun Jilin, China \\ ${ }^{2}$ Ministry of Education Technical and Vocational Education and Training, Sudan \\ *E-mail: sisnos472@outlook.com
}

\begin{abstract}
Technical and Vocational Education and Training (TVET) system can play a significant role in providing human resources to enhance the structure of economic development in developing countries. However, despite the introduction of this kind of education in as early as 1902, there is still no significant progress and achievement in as far as Sudanese TVET system is concerned. This paper attempts to address the challenges and opportunities in developing countries, a case study of Sudan. The study was done in technical secondary schools and vocational training centres in Khartoum, Sudan. The sample size was 7 participants which was obtained through purposive sampling. The data was analysed qualitatively basing on thematic analysis. Both primary and secondary data were collected. Primary data were collected through open-ended interview from 2 ministerial experts in TVET, 4 students and 1 parent. Secondary data involved the contextual analysis from empirical studies. The findings revealed that; although in developing countries, governments persistently call for TVET development, there is still a number of restrictions hindering this field to attain the required standards and success such as; management system, teacher/instructors and training program, curriculum and pedagogy, financial support, the misconception of society and technology integration. Finally, the study recommended that TVET administration should implement what has been drawn internationally.
\end{abstract}

Keywords: TVET; Education; Developing Countries; Labour market; Economic development; ICT.

DOI: $10.7176 / \mathrm{DCS} / 9-10-09$

Publication date:October $31^{\text {st }} 2019$

\section{Introduction}

Technical and Vocational Education and Training (TVET) is the type of education that prepares an individual for a specific career, or a professional position depending on the state's policies in that particular country for labour market needs (Haramoto, n.d.; Najafabadi, Poorsadegh, \& Mirdamadi, 2013; Ramadan \& Chen, 2018; Seng, 1965; Green, Oketch, \& Preston, 2004; Oketch, 2007).

According to the Sudanese TVET policy, TVET is the process of providing the students with all the knowledge and skills for the world of work (MLHRD, 2013). Although TVET system represents key factors for the nations' economic growth and sustainable development, it still does not receive a great deal of concern from the society and decision makers especially in developing countries (Atari \& McKague, 2015).

Since the partition of South Sudan from Sudan in 2011, approximately 75\% of the oil was lost, agricultural activities became very small compared to a couple of years before and small industries like automobile and trucks assembly were hampered. Basing on the report of the Ministry of Labour and Human Resources Development (ILO; MLHRD, 2013) it declared that with all these circumstances, Sudan's population is anticipated to increase in the near future with the majority being the young generation hence experts predicting that Sudan will witness extreme poverty soon. Consequently, there must be alternative economic activities to be focused on.

Table: 1 Demonstrate a report of total employment in Sudan

\begin{tabular}{llc}
\hline Category & Total employed & $\mathbf{6 , 6 7 7 , 4 1 0}$ \\
\hline \multirow{2}{*}{ Area } & Urban & $34.1 \%$ \\
& Rural & $54.5 \%$ \\
Gender & Nomadic & $11.4 \%$ \\
& Men & $76.1 \%$ \\
Employed age & Women & $23.9 \%$ \\
Unemployed age & $15-59$ & $39.5 \%$ \\
Youth & $15-59$ & $17.9 \%$ \\
\hline
\end{tabular}

Source: (Ibrahim, et, al., 2014) 
It has been suggested that to build a well-structured human capital in such a country, life-skill learning should be conducted, Dakar world forum (2000). Further still, the Global Monitoring Report (GMR 2015) stated that skill training alone did not create jobs so the emphasis on basic skills in Education For All (EFA) encouraged a rethinking of TVET's purposes so that, the new supported policies of the definitional and clarification of skills was adopted by United Nations Educational, Scientific and Cultural Organization (UNESCO) which is expected to improve TVET indicators both nationally and internationally (UNESCO, 2015).

Basing on the aforementioned information which declared the definition and the importance of the TVET system in Sudan, a number of factors have been put in place to rehabilitate Sudanese TVET system since the beginnings of the 20th century as a starting point of technical and vocational education until now, but TVET practically has not progressed. Poor students performance, lack of skills among the students and a mismatch of qualifications and competitiveness towards labour markets are the most prominent dilemmas related to the TVET today (Union, 2007). Ahmed, (2010) stated that a set of reasons had been put in place to monitor whether those causes were associated with Macro level, Micro level and Meso level. Macro level is a national policy and unified conceptual framework for TVET, teachers as well as technology integration. Micro level is a regional level that is represented as public and private sector, at this level, there would have contributions such as teachers, students training, providing some equipment and technical support as well as finances. Meso levels is the institutional or school management's role to encourage stake holders for innovation and creativity by providing a democratic environment inside the institutions/school.

Therefore, the fruitful procedure to overcome the challenges currently in Sudanese TVET (management system, teacher/instructors and training program, curriculum and pedagogy, financial support, the misconception of society and technology integration) hindered the progress of TVET to become more valuable and contribute to the social development, economic growth and sustainable development. There's need to follow the international experiences and frameworks that will lead to the TVET reforms like UNESCO's and African Union (AU) frameworks, European, Asian and some developed country's experiences.

\section{Research questions}

I. What are the challenges that restricted the progress of TVET system in Sudan?

II. What were the highlights were adopted by the developed countries in their TVET systems?

III. What can be done to adopt these experiences in the Sudanese TVET system?

\section{Literature review}

Although, there is no perfect or suitable education and training system that will unify the needs of all countries around the world, the background, society and economic needs are a vital role which administer the TVET character as well as its mission and vision (Seng, 1965). In this section, the literature draws attention to how TVET globally is being mapped and managed in order to become fruitful and realize the nation's goals. According to Agrawal, (2013); Seng, (1965), there are some international experiences such as from Singapore that followed very distinguished policies and recommendations which made the VTE a First-Class Model in the world. The literature also showed some experience from Finland that is leading the world in the global Program for Institutional Students Assessment (PISA) besides the distinctive Secondary Vocational Education they possess (Merilainen, Isacsson, \& Olson, 2018; Virolainen, 2014). All these experiences can be adopted so as to discover the opportunities that could be advantageous and replicated into Sudanese TVET system.

\subsection{Singapore}

Vocational and Technical Education (VTE) in Singapore aims at preparing graduates with essential work-related skills and standards for the industry and economy. Seng, (1965) stated that; "the real test of the success of VTE is the employability of the graduate, personal development, opportunity for further education and career development, public acceptance, and image". Basing on the history and the current situation of Singapore as one of the developed countries, after her independence, it had been understood that traditional trading, commerce, and service sectors would not deliver satisfactory jobs but the Singaporeans realized that the VTE would be the key factor of the diversity and economic growth acceleration, thereafter strategic plan had to be launched by the Singapore government. As a result, systematic procedures had to be followed to upgrade the VTE like; the proper way of tackling the drop-out issue related to the low achievement of the students, various routine reforms to stay relevant to the needs as well as allocating a proportion of donations to support education and training (EduSave account) system, (Law, 1984; Seng, 1965).

The Singaporean strategic plan that was implemented was characterized of transitional stages that started from the 1960 s to 2000s which is presented as following; a factor-driven economy, which is focused on the labour market, an investment-driven economy, that is focused on the mechanisms that develop the capital investment and the 
innovation- driven economy that relates to knowledge (Agrawal, 2013; Seng, 1965; Seng, 2012). Exhaustive activities and concerted plans with the local community and international partners were done through these three phases over the years (Seng, 1965). The most interesting lesson that can be taught from Singapore's VTE system is the transformation of the country from the third-class to the first-class globally within only (30-40) years whose focus was on the workforce linked knowledge, skills and values. Further still, when these strategies were shared with the community for the targeted project, its implementation was much easier.

\subsection{Finland}

The Finnish National Board of Education, (2010) reported that; vocational education and training (VET) and vocational competence played a major role in reinforcing economic competitiveness and wealthy (Tessaring \& Wannan, 2010). Competencies and multipurpose skills are the features of the world markets' future which broaden with regeneration of competencies that are demanded. So, they argued that the VET development depended on quantitative and qualitative data anticipation. In another words; quantitative information, refers to the long-term labour market demands attached with educational needs and qualitative information are the skills that are needed at the national level respectively which are both named data anticipation.

Data Anticipation information on educational needs required challenges' solutions to the country's demographic development and the increasing impact of the global economy. The targeted category in this system is vocationally/professionally oriented education and training intended for young people, i.e. upper secondary vocational education (SVE), vocational education and training (VET), polytechnic education and university education which mainly lasts from (3-8) years, depending on the level of education. The Finnish National Board of Education aims at achieving this program by 2020 (Hanhijoki, Katajisto, Kimari, \& Savioja, 2012).

The lesson that could be learnt from the Finnish experience of secondary vocational education is its curriculum; this curriculum consists of a wide range of subjects being taught whether in high school or continuing education in order to widen employment opportunities. Its ability to be renewed so as to increase the cooperation between schools and the labour market, its being developed and improved through long-term work in terms of training and qualifications to attract and allow students to enrol in the higher education and its structure being changed to three years full-time study and one quarter of this time allocated for general educational subjects like; science, math, social studies, modern languages and local language (Merilainen et al., 2018) makes it bearable and desired to be adopted in a country like Sudan.

\subsection{Africa:}

According to African Union as cited in Oketch (2007), the survey which was conducted at seven countries in Africa (Botswana, Egypt, Ghana, Senegal, Seychelles, Tunisia, and Zimbabwe) defined that; TVET refererd to a series of learning experiences that related to the world of work and which might take place in a variety of learning contexts, including educational institutions and the workplace (Oketch, 2007). However, TVET also includes informal learning which occurs out of the schoolyard (informal learning takes place casually or by-product of other activities). Informal learning very often does not adhere to the rules and regulations as well as the standard curriculum of formal education (Green et al., 2004; Union, 2007). The education systems in Africa can be shown at four levels such as: primary education(6-8 years), lower - secondary education (3-4 years), upper - secondary education (2-3 years) and higher education lasting for an average of 3-5 years (Oketch, 2007).

The African Union's vision of “an integrated, peaceful, Africa's prosperity, driven by its own people to take its rightful place in the global community and the knowledge economy" has not been realized in these seven countries because, there were priority areas that became challenging. Thus, the Strategic Policy Framework attempts to address these issues such as; poor perception of TVET, gender stereotyping, instructor training, linkage between vocational and general education, linkage between formal and non-formal TVET, linkage of TVET to the labour market, traditional skills, business management and entrepreneurial training, and, harmonisation of TVET programmes and qualifications (Union, 2007).

\subsection{Sudan}

In Sudan, the TVET system was launched in the year 1902. It started with technical secondary school at Gordon Memorial College [present University of Khartoum] (Ahmed, 2010; UNEVOC-UNESCO, 2005). It is upper secondary school-based following the basic school certificate, it involves Vocational Training Centres (VTCs), Artisan Institutions (AIs), Technical Secondary Schools (TSSs) and Technical Colleges as higher education (MLHRD, 2013). Furthermore, TVET is characterized by the flexibility that could accept unlimited categories of personalities with different academic levels with the view to seek employment, particularly for vast amounts of young people enrolled in the informal vocational training system (Union, 2007). 
TVET has the capacity to accommodate all the segments of society. Hence, according to (MLHRD, 2013) there were three targeted groups to benefit from TVET including; pre-employment training; for men and women who finished the first or second round of formal education in preparation for employment, in-service training and retraining for people who work in public or private sector and desire to update and upgrade or professionally change which is called Continuous Vocational Training (CVT), as well as for those who lost their employment due to the diversity of radical changes in technology or closing down of an economic sector. Finally, social dimension meaning people with disability, disadvantaged people in the labour market due to the geographical location, people from conflict areas and demobilized soldiers, old workers and school dropouts (Atari \& McKague, 2015; Oketch, 2007).

Figure 1: Demonstrates the technical and vocational and education tracks

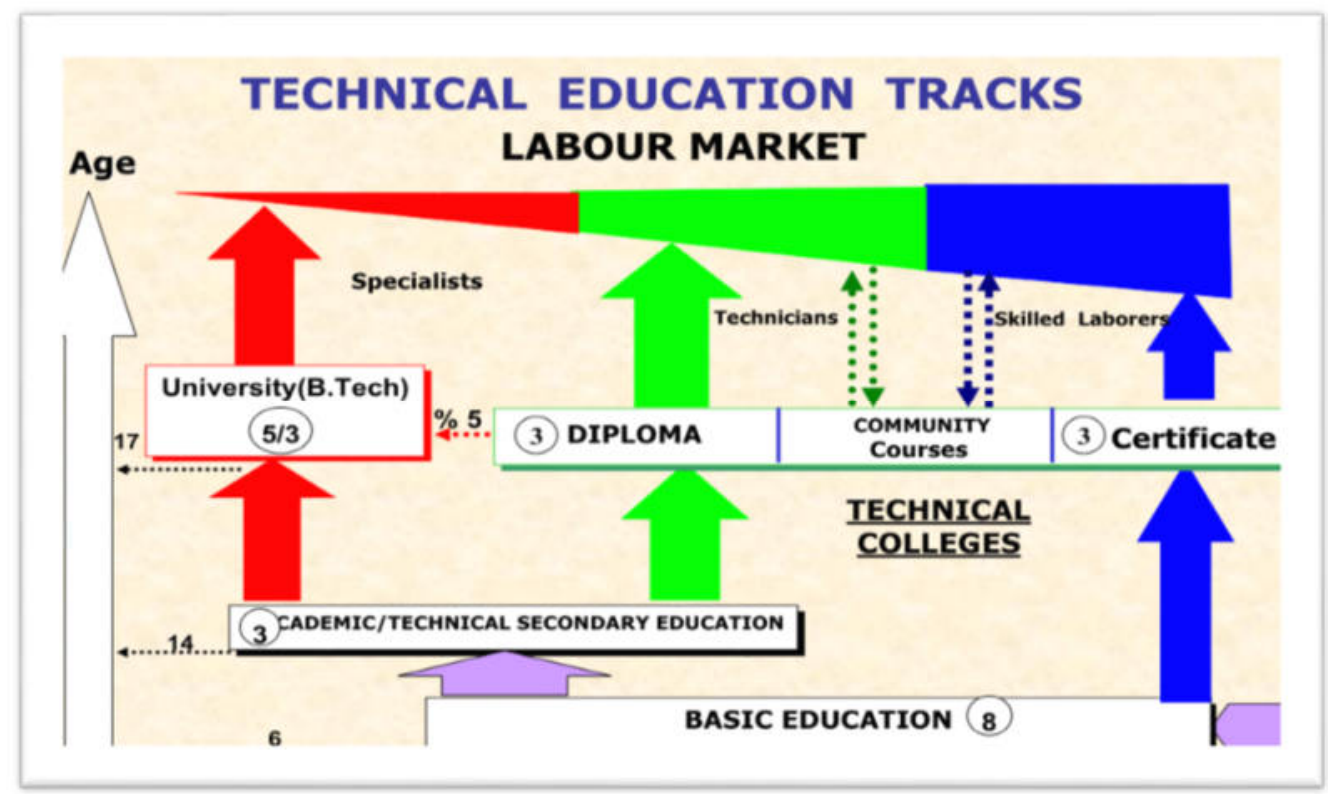

Source: (UNEVOC-UNESCO, 2005)

In this case study of TVET in Sudan like any other African country, TVET has its own policy which is defined "as being concerned with the acquisition of knowledge and skills for the world of work" (MLHRD, 2013). The term TVET here wraps technical education which is presented as secondary school-based and vocational training as an apprenticeship-based training which becomes a common denominator that links both of them. The value of training is measured by the quality of competencies that are produced regardless of the level (ibid).

According to the report of the International Labour Organization (ILO) in Khartoum (2013), it was revealed that, there was no clear, comprehensive and articulated policy statement in as far as TVET was concerned. Rather, there was a number of separate laws, decrees and practices covering separate aspects of TVET. The National Council of Technical and Technological Education (NCTTE) as a coordinator is responsible for bringing general coherence into the TVET system and works side by side with Federal Ministry of General Education (FMGE) which is the official state ministry that handles technical secondary schools and artisan institutions as well as the Supreme Council for Vocational Training and Apprenticeship (SCVTA) which works alongside the Ministry of Labour and Administrative Reform (MLAR). TVET in Sudan is characterised with:

- Ineffective involvement of the social partners.

- Neglecting the skills needed for the agricultural sector and the informal economy.

- Division and replication of effort due to poor coordination.

- Mismatch between labour market needs and skills offered by TVET institutions.

Despite the declaration of the Sudanese government that TVET should reach $60 \%$ of all education system in Sudan, less has been realised in result, for example, the technical secondary school students' ratio in the whole Sudanese state is only 5.03\% (Educational Statistics in the year 2010/2011). Recently, the Minister of Education approved that the TVET skilled personnel had reduced as reported (only $0.3 \%$ ) due to the absence of vision and central 
management (Alrakoba.net, 2019). And recommendation has been directed to make policy review and sector output and to pay attention to TVET skills development is required for the labour market" (Alrakoba.net, 2019).

Based on the aforementioned report, there were some practical and current challenges that restricted the progress of Sudanese TVET system such as; management system, teacher/instructors and training program, curriculum and pedagogy, financial support, the misconception of society and technology integration. All these issues need to be studied in order to gain standard solutions which would be very instrumental in the enhancement of TVET reform and contribute to the sustainable development and economic growth of Sudan in the near future. Therefore, according to the developed countries experiences in the TVET field, the literature showed that the research gap lies in the following; lack of the authentic learning (technical practice), mismatch of skills and competences, and the absence of the $21^{\text {st }}$-century skills (smart technologies).

\section{Methodology}

A qualitative approach was adopted in this study. Multiple sources of data collection were employed including primary and secondary data. Primary data came from informal interviews with some experts, students and parents giving their ideas about TVET and the challenges they faced in the process. Secondary data came from the previous studies reviewed and some reports (Heaton, 2008; Hox \& Boeije, 2005). For data collection procedure, the researcher selected a sample of (7) respondents from three groups as follows; group one involved two respondents (experts); principal (VTC), deputy principal (TSS), group two involved four students; three formal students studying at VTCs and one informal students (apprenticeship) and group three involved one parent. An open-ended interview session was conducted which lasted for 20-30 minutes. The interviews were held in Arabic hence the researcher had to transcribe the issues into Arabic and then translated into English. In data analysis, the researcher attempted to understand and explain the patterns that he later categorized into themes as elaborated by the participants (Creswell \& Creswell, 2017; Merriam, 1998). With secondary data analyses, content analysis was used.

\section{Presentation, Analysis of the Findings and Discussion}

The analysis of the results below includes the answers of the questions that related to the challenges that restricted the progress of TVET system in Sudan, the actions that were adopted by the developed countries in their TVET, and the experiences that can be adopted in the Sudanese TVET system.

\subsection{Management}

Managers play an important role in TVET as they represent professionals and policymakers inorder to understand the authority and legislation that is related to the teaching and learning process, funds and project management. According to (UNEVOC, 2018), it was reported that for one to manage a TVET institution, he/she must possess the required qualifications and relevant skills such as decision-making, adaptation to change so as to achieve the desired goals. Subotzky, Njuguna, \& Afeti, (2008) asserted that; Africans lack the power of managing institutions because they do not think deeply about the market demands, industrial and economic situation of their countries. This weak management eventually leads to less internal efficiency of the institution. Furthermore, the study conducted by (Simiyu, 2009) found out that age, academic qualification and training are the determinants of the principals position to achieve institutional development and prestige. In Sudan, management represents a factoring issue that remains complex in the TVET system whether at the state, regional or institutional level. TVET managers at all levels are selected basing on the accumulation of experiences but with lack of skills and training (Subotzky et al., 2008) hence the hurdle to find the right placement in administration of TVET institutions as well as the absence of young generation among the TVET staffs.

Based on the respondent, the deputy principal expressed that, “...most managers or principals in Sudanese TVET institutions are technical secondary school graduates with lack of skills and in-service training in terms of management which has affected the leadership performance, the relationship with staff as well as teaching and learning outcomes. The administrators are the heads of the TVET institutions so it is very important to be knowledgeable as well as having foreign language skills so as to communicate with foreign delegation...".

This finding matches with (Simiyu, 2009) who discussed that the principal creates a climate that permits students and staff to carry out their roles for the common good of the institution in terms of the teaching and learning process. Also, he stressed that the principals should know that the work carried out by the institute was the best way of advertising its services and allowing the community to perceive the graduates' reliability. According to (RMoE, n.d.; Union, 2007), managers should be trained and upgrade their skills basing on qualifications framework, accreditation standards, assessment guidelines, quality assurance and accountability frameworks. 
Hence, these criteria of selecting TVET administrators should base on the qualifications, character as well as a continuous training program to gain skill-sets.

\subsection{Teacher, instructors and training programme}

Teachers are a pillar of the teaching and learning process, so they need to be prepared properly to improve TVET institutions' quality in an innovative and creative environment to meet the changes (Härtel, 2017). During the training workshop about technical and vocational education in Khartoum, in promotion or support of creation of youth employment opportunities, the Sudanese commissioner for technical education declared that "majority of teachers of technical and vocational school's qualifications needed to be advanced/upgraded because they possessed a (two-three) years diploma in technical secondary school (TSS) and artisan institution certificates (VTC).

Additionally, the deputy principal mentioned that; “... TVET teachers were accommodated directly as they graduated from technical secondary schools to enrol into teaching and learning due to scarcity of technical teachers with bachelor's degree as the least qualifications..." He further asserted that, “... at the beginning of TVET in Sudan, teachers were meant to go to United Kingdom and Egypt for a two-three years course to upgrade their qualifications in both pedagogical and technical skills, but this program was phased out due to economic crisis by the beginning of 1980 s ...". These findings correspond with the report from Rwanda, which stated that; lack of suitable qualifications, pedagogical qualifications and industrial deficiency were the worst challenges faced in the TVET staffing (RMoE, n.d.). It was noticed that, none of these qualifications were up to the standard required of a technical teacher of education that could train a bachelor student nor prepare a teacher professionally especially for TVET. Hence, the shortage of bachelor degree holders led to poor performance of teachers in terms of pedagogical practices inside the classroom which eventually negatively affected the students' performance too. The same issues had been reported in Europe, Commonwealth of Independent States (CIS) and North America such as; lack of clear standards, different certification, lack of training assessment, mismatch between local and international framework as well as standards (UNEVOC, 2018).

The final report of the African Union (2007) appreciated the role of teachers in TVET where pedagogical competence was seen as a fundamental factor for the positive implementation of TVET strategy. As a result, great efforts were put into consideration by governments in order to train and keep teachers on the right track as well as rewarding and motivating them with subsidies and loans which could raise the degree of enthusiasm amongst them. More so, researchers recommended that, due to the nature of TVET, there were on-going training programs that had to be existent so as to make teachers and instructors abreast with new technology that the labour market needed (Ahmed, 2010). Therefore, TVET teachers need to be well prepared in terms of qualifications, competencies and professional development, in addition to continuous evaluation which will make the teachers and instructors keep up-to-date in terms of theoretical knowledge, pedagogical practice and technological skills (UNEVOC, 2018; Union, 2007).

\subsection{Curriculum and pedagogy}

National Curriculum Centre is one of the departments of the Federal Ministry of General Education in Sudan that designs the whole country's educational document (curriculums). The main feature of TVET curriculum is that technical secondary school should last for three years with a $60 \%$ of theoretical knowledge in the subject during classroom teaching and $40 \%$ for practical skills within the school's workshop. In an artisan institution, studying should be for two years $(40 \% / 60 \%)$ respectively. Students should spend two days per week on-job training in the industrial centre and for the vocational training centres studying three years included 6-9 months on-job training $(30 \% / 70 \%)$ respectively. It is observed that the general subjects included; religious studies, languages, mathematics and science as the same as academic education ( $60 \%$ of the curriculum) except for the artisan and vocational training centres.

Ahmed, (2010) reported that, curriculum and pedagogy in Sudanese TVET system was quite weak because it had not been controlled by experts/specialists. In the same vein, there was/is a shortage of school textbooks and official curriculum guidelines for students and teachers respectively. Furthermore, there was/is limited practice during the practical lessons that led to production of poor/low quality skilled students due to the shortage of technical tools/equipment". In this aspect, the respondent deputy principal said that, “...to date, there is a new syllabus for technical secondary school but, this syllabus seems not to be subjected to the standards required, it might have been produced by experts in a particular field, which obviously did not portray works of active practitioners. In addition to that the school workshops are quite poorly stocked with tools/equipment, which meant, the teacher focused only on indoctrination...". This findings agreed with Ahmed, (2010), whose view was that despite the curriculum reform that had been implemented, there still, remained challenges because it had not been controlled by experts. Additionally, (Haramoto, n.d.) mentioned that; in African countries, the practices of theoretical 
methods were very dominant which provided nothing in practical skills for the students and at the same time, the curriculum here only delivers the achievement of white collar jobs instead of practical/technical skills that could enhance the capability of students for specific jobs (Ahmed, 2010). According to the author's point of view about TVET, the curriculum which is currently used in TVET is outdated and requires revision so as to suit the needs of the country and persons.

Therefore, the findings suggested that, there should be a general reform in the curricular design, syllabus design, pedagogy, practical lessons (tools/equipment) based on the labour market needs and demands which will stimulate the teaching and learning environment that will be characterized by innovation, invention/creativity, problemsolving as well as corporation to prepare students professionally for their work life. These should put into consideration that the curriculum should include activity based-learning as well as skills, knowledge and attitude (Anane, 2013; Dubois, 1993; Sampson \& Fytros, 2008). It is also important to involve the private sector and employers in the process of determining the status of the curriculum.

\subsection{Financial support}

Funding and equipping TVET institutions is a vital policy and strategy to draw the map for policymakers to be taken into account (AU, 2007). Furthermore, TVET institutions are more expensive in comparison to other institutions that offer other kinds of education (Darvas \& Palmer, 2014). Studies revealed that poor facilities, inappropriate equipment and under-funding were the common criticisms from TVET in developing countries which impacted on institutions to purchase the significant tools so as to improve the quality of TVET (RMoE, n.d.). Based on the study findings, the deputy principal exclaimed that; “...stake holders described the impact of the decentralization of the education system as catastrophic and the fact is that education was referred to the provinces in the light of the scarcity of the allocated financial resources of only $2.5 \%$ of the general budget instead of $15-20 \%$ in accordance with international standards ...".

In terms of project venturing (capital funding), the African Development Bank (ADB) has a great impact on the maintenance and rehabilitation of Sudanese technical secondary schools which is running now. More still, UNIDO has built and entirely equipped new VTCs that belong to the Ministry of Labour and Human Development (MLHD)-Khartoum state. However, international support does not mean that it will be following through lifelong, so there is need to support our economies in terms of productivity in order to reduce the country's accumulated debt. The deputy principal said that; “... In developed countries, technical institutes have emerged mainly under the umbrella of government and industrial institutions, but the situation is quite reversed in developing countries ... consequently this results into lack of a close link between government departments, technical education institutions and labour market contributions in terms of curriculum development, training for graduates to be prepared for the labour market..." This finding is related to Zanariah, (2016) who confirmed that the Malaysian government companies and TVET institutions (more than five effective ministries and public institutions) work together so as to make implementation of TVET policies, funds and support easy. The principal stated that; “...majority of TVET institutions especially TSSs depends on annual students' fees which is paid by parents to fill the shortage of the state funds so as to clear off the dues for the services rendered such as; electricity fees, practical tools, teaching materials, examination and so on. The government only provides teachers' salaries and some managerial costs but to a minimal extent...".

While the deputy principal added “...Poor funding in TVET education has generally weakened the school environment in terms of decline in teacher performance that has eventually led to poor performance of students hence low rates of technical education graduates to $3.5 \%$ instead of $60 \% \ldots . .$. . Basing on these findings, the study figured out the value of merging efforts by the public and private sectors which is recommendable in Africa so as to enhance TVET as reported in (Union, 2007). The services of the private sector in TVET in some African countries are delivered by both government and private providers especially Church-based like in Ghana, Tanzania, Zimbabwe and Senegal as well as NGOs. But the public sector offers little support for providers in the private sector in terms of salaries, loans, authorization licences skilled labour, to mention but a few. As a result, there must be collaboration between government, stakeholders, providers and donors in order to plan for availing of equipment/ materials (teaching aids) that match today's TVET standards in liaison with those in developed countries (Darvas \& Palmer, 2014; Union, 2007). Henceforth, this study suggests that state ministries should be involved as the main participants and contributors in Sudanese TVET system.

\subsection{The role of society}

Normally, in developing and some developed countries there is less attention paid to TVET institutions more so those in rural areas so, no or poor action from the governments is taken but only focus on those in the capitals cities (Konayuma, 2008). In other words, there is lack of dissemination of TVET institutions' voice, unconvinced outcomes and hence poor perception by the society. The deputy principal exclaimed that; 
“...According to data which was presented at the technical workshop about TVET Development, it was revealed that in secondary education, governmental academic schools reached (2358) while the number of technical schools did not exceed (110). These were the main reasons that bred reluctance by families to enrol their children into technical education: TVET does not fulfil the aspirations of children and guardians in the future; the perception of TVET as second-class education, the ambiguity of the acceptance policies from ministry of education in terms of grades scored, curricula of the technical education do not abreast the labour market needs, the limit of technical education students enrolment for admission to technical colleges/universities and the inability of technical diploma holders to continue their postgraduate studies...".

According to the students' point of view, they collectively agreed that; they travel from their villages to the capital (Khartoum) for better educational facilities due to low academic achievement in the rural areas where they originate from, and also, some think that they are escaping from the hard academic subjects but opt for short courses that will help them attain professions though it proves difficult for them to continue to reach higher education (upgrade) (Union, 2007). This is the same desire and perception of those who joined the informal TVET institutions.

Therefore, a radical decision should be made to sensitize families and their children about the importance of TVET so as to raise their enthusiasm. Sulaiman, et, al., (2015) are in line with the researcher that; great efforts should be taken to disseminate the value of TVET among the stakeholders most importantly those who render technical services to society who will later impart knowledge to society about TVET and its aims and objectives. Mustapha \& Abdullah, (2001) assert that, there is need to change the socials' mindset towards TVET so as to avert the negative stigma and let the society accept TVET as vital education for one's improvement in the standards of living as well as the country's economic development.

NCTTE and SCVTA should make awareness programs on media channels such as radios, television and Facebook to mention but a few about the importance of TVET education so as to provide gifted and academically excellent students the opportunity to prove their worth through attaining livelihood skills as well as stimulating them psychologically and morally in training sessions abroad. Above all, TVET institutions have to be enhanced and developed particularly TSSs to raise the academic performance among students and job opportunities should be availed to the TVET graduates in both government and private firms.

\subsection{Technology integration}

In this section, the study took into account the technology integration from two stances; technology as a modern tool and equipment that would be used in the workshops and technology in form of electronic devices that can be used to aid the teaching and learning process where both require high-quality skills to manipulate this digital industrial revolution.

In Sudan, there is need for improved technology so as to develop the required skills as discussed by Nour, (2013). The findings revealed that low quality education was the resultant effect due to poor skills in terms of technological availability and awareness of the workers. Consequently, Sudan depends on foreign technology due to the deficiency in industrial performance so this study appreciates the role of technology for its impact on education that will link students to improved (ICT) skills hence economic growth and development (Nour, 2015). Similarly, UNEVOC, (2018) advocates for integration of ICT theoretically and practically in the teaching/learning process of TVET studies which will help teachers and students hence coping with the international world in TVET.

From the results, the principal and deputy principal agreed that, “...technology has a great impact in the teaching and learning process in TVET. Regardless of the current progress in technology revolution, there is still a long way for the people to embrace this advanced/improved technology (attitude) as they perceive it as time consuming and costly hence unable to implement as expected especially the current aged/mature personnel in the system. Still to note, the parent respondent stressed that ICT is important in TVET education as a formal way of embracing advanced technology unlike in the informal system. These findings are in line with studies that were conducted in Sudanese TVET system which explained the values and importance of ICT as a modernization necessity in this field of TVET. However, there are some hindrances to the integration of ICT in TVET such as; connectivity, teacher skills (knowledge about ICT) and classroom preparation (Ahmed, 2010; Ramadan \& Chen, 2018; Ramadan, Chen, \& Hudson, 2018).

Basing on the findings in this study, ICT is an elevator of TVET education in the sense that it benefits and improves the teaching/learning process as follows; resourceful and improved learning outcomes, supports student centredlearning, produces job creators than job seekers and, encourages real-life learning (UNEVOC, 2018). For teachers, ICT has improved their pedagogical practices, encouraged them to attain further training so as to acquire improved 
skills of teaching through Open Distance Learning (ODL) or Open Educational Resources (OER) upgrading their information technology skills as well as communication skills (Nour, 2015; UNEVOC, 2018).

\section{Conclusion}

This paper concludes that TVET management/administration should follow the standard qualifications of TVET teachers which is a minimum of a bachelor degree and international framework. TVET reforms have to be done so as to keep up with international experiences as a transfer from conventional teaching to competency-based technology and learning and focus on what the national labour market needs. Ministry of Education should involve the public-private partnership (PPP) contributions and participate in providing funds for TVET to improve the status of TVET education. For society, stake holders should embrace the role played by TVET education so as to secure a brighter future for both their children and the country at large. In terms of ICT advancement, competencybased technology paradigm has to be implemented to make up-to-date with modern technologies for practical skills, innovation and creativity (hand-craft and entrepreneurship).

Finally, the study recommends that there should be a comprehensive masterplan in TVET over time to bring out a very clear policy, vision and the objectives, for instance enabling reviews to overcome the challenges related to the teaching and learning process and how TVET can be used as an avenue to industrial and economic development in the country through:

a. Addressing the problems facing technical education by taking the examples and experiences of the countries that have emerged in this field as study cases.

b. Develop interim plans (short, medium and long term) in accordance to the requirements/needs of the labour market for economic growth gradually from local to global.

c. Focusing on the training of TVET teachers nationally and internationally, especially from those countries that have embraced our efforts and have made significant progress in the field of technical education.

d. Upgrade educational competencies by sending teachers to universities that will provide an academic exchange system so as to develop and compete in educational research.

e. Excellent/outstanding/gifted students should be motivated through scholarships/bursaries.

\section{References}

Agrawal, T. (2013). Vocational education and training programs (VET): An Asian perspective. Asia-Pacific Journal of Cooperative Education, 14(1), 15-26.

Ahmed, H. (2010). Building Capacity of Teachers and Trainers in Technical and Vocational Education and Training (TVET) in Sudan. Retrieved from https://docplayer.net/5061408-Building-capacity-of-teachersand-trainers-in-technical-and-vocational-education-and-training-tvet-in-sudan-case-of-khartoum-state.html

Alrakoba.net. (2019, February). The Ministry of Education. https:/www.alrakoba.net/news-action-show-id315423.htm

Anane, C. A. (2013). Competency based training: Quality delivery for technical and vocational education and training (TVET) institutions. Educational Research International, 2(2), 117-127.

Atari, D. O., \& McKague, K. (2015). South Sudan: Stakeholders' views of technical and vocational education and training and a framework for action. Journal of Vocational Education \& Training, 67(2), 169-186.

Darvas, P., \& Palmer, R. (2014). Demand and supply of skills in Ghana: how can training programs improve employment and productivity? The World Bank.

Dubois, D. D. (1993). Competency-Based Performance Improvement: A Strategy for Organizational Change. ERIC.

Green, A., Oketch, M., \& Preston, J. (2004). Global report on technical and vocational education and training.

Hanhijoki, I., Katajisto, J., Kimari, M., \& Savioja, H. (2012). Education, training and demand for labour in Finland by 2020. Helsinki: Finnish National Board of Education.

HARAMOTO, Y. (n.d.). Challenges of TVET in Developing Countries with a Case Study of Korea's Aid in Sudan.

Härtel, M. (2017). Germany: BIBB. Using ICTs and Blended Learning in Transforming TVET, 59.

Heaton, J. (2008). Secondary analysis of qualitative data: An overview. Historical Social Research/Historische Sozialforschung, 33-45.

Hox, J. J., \& Boeije, H. R. (2005). Data collection, primary versus secondary.

Ibrahim, I. K., Mahmoud, A. M. H., Powell, M., \& Abdelrahim, H. (2014). Skills Development in Sudan. Cairo, Egypt: International Labour Organization. Retrieved from http://www.ilo.org/wcmsp5/groups/public/@africa/@ro-addis_ababa/@srocairo/documents/publication/wcms_243636.pdf

Konayuma, G. (2008). Policy Frameworks: Major Policy Issues in TVET in Africa. In All Africa IVET A Conference. 
Law, S. S. (1984). Trend of vocational training in Singapore. Vocational and Industrial Training Board.

Merilainen, R., Isacsson, A., \& Olson, S. (2018). Secondary Vocational Education in Finland. Online Submission.

MLHRD. (2013). Sudan TVET Policy. Khartoum. Retrieved from http://www.ilo.org/wcmsp5/groups/public/@africa/@ro-addis_ababa/@srocairo/documents/publication/wcms_243649.pdf

Mustapha, R., \& Abdullah, A. (2001). Globalization and Its Impact on Technical-Vocational Education and Training in Malaysia.

Najafabadi, M. O., Poorsadegh, M., \& Mirdamadi, S. M. (2013). Challenges of Application ICTs in Technical and Vocational Training from Students 'and Instructors 'Perception in Maragheh. International Journal of Advanced Science and Technology, 54, 54-112.

Nour, S Mohamed. (2015). Information and Communication TechNour, S. M. (2015). Information and Communication Technology in Sudan. Springer.nology in Sudan. Springer.

Nour, Samia Mohamed. (2013). Technological change and skill development in Sudan. Verlag Berlin Heidelberg: Springer Science \& Business Media. https://doi.org/DOI: 10.1007/978-3-642-32811-4

Oketch, M. O. (2007). To vocationalise or not to vocationalise? Perspectives on current trends and issues in technical and vocational education and training (TVET) in Africa. International Journal of Educational Development, 27(2), 220-234.

Ramadan, A., \& Chen, X. (2018). Teachers'perceptions on ICT Integration in TVET Classes: A Case Study in Khartoum State-Sudan. People: International Journal of Social Sciences, 4(2).

Ramadan, A., Chen, X., \& Hudson, L. L. (2018). Teachers' Skills and ICT Integration in Technical and Vocational Education and Training TVET: A Case of Khartoum State-Sudan. World Journal of Education, 8(3), 31.

Rwandan, \& Education, M. of. (n.d.). TVET_Policy_Final.pdf. Retrieved from http://mineduc.gov.rw/fileadmin/user_upload/pdf_files/TVET_Policy__Final.pdf

Sampson, D., \& Fytros, D. (2008). Competence models in technology-enhanced competence-based learning. In Handbook on information technologies for education and training (pp. 155-177). Springer.

Seng, L. A. W. S. (1965). Vocational technical education and economic development: The Singapore experience. Toward a Better Future: Education and Training for Economic Development in Singapore Since, 114-134.

Seng, L. S. (2012). Linking TVET with economic expansion Lessons from Singapore, 238-242. Retrieved from file://G:/P 4/Linking-TVET-with-economic-expansion-Seng.pdf

Simiyu, J. (2009). Revitalizing a Technical Training Institute in Kenya. Bonn, Germany: UNESCO-UNEVOC International Centre for Technical and Vocational Education and Training. Retrieved from http://www.unevoc.unesco.org/fileadmin/user_upload/docs/CS1_SIMIYU_formatted_final.pdf

Subotzky, G., Njuguna, N., \& Afeti, G. (2008). Differentiation and Articulation in Tertiary Education Systems: A study of twelve countries. The World Bank.

Sulaiman, N. L., Salleh, K. M., Mohamad, M. M., \& Sern, L. C. (2015). Technical and vocational education in Malaysia: policy, leadership, and professional growth on Malaysia women. Asian Social Science, 11(24), 153.

Tessaring, M., \& Wannan, J. (2010). Vocational education and training: Key to the future. Lisbon-CopenhagenMaastricht: Mobilising For.

UNESCO, G. M. R. (2015). Education for all 2000-2015: Achievements and challenges. EFA Global Monitoring Report, 500.

UNEVOC-UNESCO. (2005). The Promotion and Development in SUDAN. AVAILABLE Online Pdf, 21. https://doi.org/10.1109/ICSTM.2015.7225390

UNEVOC. (2018). UNEVOC TVET Leadership Programme 2018 Capacity building for transformational TVET leaders: Vision , knowledge and skills. Bonn, Germany. Retrieved from unevoc.unesco.org/up/UNEVOC_TLP2018.pd

Union, A. (2007). Strategy to revitalize technical and vocational education and training (TVET) in Africa. In Meeting of the Bureau of the Conference of Ministers of Education of the African Union (COMEDAF II+) (pp. 29-31).

Virolainen, M. (2014). Finnish Vocational Education and Training in Comparison: Strengths and Weaknesses. Online Submission, 1(2), 81-106.

Zanariah Ahmad, \& Ministry of Higher Education Malaysia. (2016). Education 2030 Launch and Symposium. Education 2030 Launch and Symposium, (August). Retrieved from https://www.moe.gov.my/images/Terbitan/Rujukan-Akademik/Presentation-Education-2030-LaunchSymposium-23rd-August-2016-Hotel-Istana-Ballroom-Kuala-Lumpur/Zanariah-Hj-Ahmad/Zanariah $\mathrm{Hj}$. Ahmad.pdf 


\section{Biography 1}

Abdelmoiz Ramadan is a teacher at Mistry of Education, Technical and Vocational Education and Training TVET, Sudan. He is PhD candidate, School of Information Science and Technology, Northeast Normal University NENU, China. He joined NENU in 2015, his project title is: Towards Integration ICT in TVET: A Case Study in Sudan. He received his Masters of education in 2009 from Sudan University of Science and Technology SUST. His project attempts to integrate ICT technologies in pedagogical practice and teacher professional development. He has published articles in international conferences and journals; world journal of education; PEOPLE: International Journal of Social Science and Springer. He is an Advisory Board Member of Teaching \& Education Research Association - TERA, Eurasia Research, and Editorial Board Member of Humanities and Social Sciences Journal.

\section{Biography 2}

Chen Xiaohui is a professor of Educational Technology at School of Information Science and Technology, Northeast Normal University,China. She got her Doctor's degree of Education from Northeast Normal University in 2005. Her research areas are mainly on Teacher Education in the Age of Artificial Intelligence, the Basic Mechanism and Intervention of Learning, the Comparative Study on the Policy. She has published several papers in International Journals and conferences. 